\title{
A New Genus and Three New Species of Pangoniini (Diptera: Tabanidae) from Bolivia
} John E Chainey ${ }^{+}$, Martin JR Hall

\author{
Department of Entomology, The Natural History Museum, London, SW7 5BD, UK
}

The genus Boliviamyia gen. nov. and it's type species fairchildi sp. nov. are described. Two new species of Esenbeckia (Esenbeckia), griseipleura $s p$. nov. and gracilipalpis $s p$. nov. are described. Esenbeckia (Esenbeckia) planaltina Fairchild is recorded from Bolivia.

Key words: Boliviamyia fairchildi n. gen., n. sp. - Esenbeckia griseipleura n. sp. - Esenbeckia gracilipalpis n. sp. - Bolivia - Tabanidae

Chainey et al. (1994) documented the 32 genera and 167 species of Tabanidae reported from Bolivia, including 1 genus and 11 species of Pangoniini (subfamily Pangoniinae). The Pangoniini are considered to include some of the most ancestral forms of Tabanidae (Fairchild 1969, Coscarón 1976). With the exception of Esenbeckia most of the genera of Pangoniini are rarely collected and appear not to be active blood feeders. It was therefore most unexpected that recent collecting in Bolivia should produce over 200 specimens of a new genus of Pangoniini at horses, baited canopy traps and electric nets. This new genus and species are described below and the opportunity is also taken to describe two new species of Esenbeckia (Esenbeckia), also from Bolivia.

\section{MATERIALS AND METHODS}

The terminology follows that of McAlpine (1981). The frontal index is derived from the length of the frons when both vertex and base are visible on the same plane, divided by the width at base. The height of the head is measured from the side with the back of the head held vertically.

Abbreviations - FSCA: Florida State Collections of Arthropods, Gainesville, Florida, USA, JEC: JE Chainey, JLA: JL Aramayo, MJRH: MJR Hall, MNKM: Museo de Historia Natural "Noel Kempff Mercado", Santa Cruz, Bolivia, NHM: Natural History Museum, London, PB: P Bettella.

\footnotetext{
This paper results from collaborative efforts, including joint fieldwork, between the Natural History Museum, London, and the Museo de Historia Natural "Noel Kempff Mercado" of the Universidad Autónoma "Gabriel René Moreno", Santa Cruz. Funding was provided through Overseas Development Administration (UK) Animal Health Programme, Project R507.

+Corresponding author. Fax: 0171-938.8937

Received 28 August 1995

Accepted 3 January 1996
}

\author{
Boliviamyia new genus \\ Type species: fairchildi sp. nov. \\ (Figs 1-4, 6-11)
}

Boliviamyia (Fig. 11) is characterized within the Pangoniini by having the eyes bare in both sexes, without pattern; male eyes with strongly differentiated large upper-median facets (Fig. 4); female frons broad and divergent towards antennae with prominent callus that is well separated from eye margins (Fig. 1); antennal flagellum with basal plate and 4 terminal flagellomeres (Fig. 2); palps swollen with short dorsal groove (Fig. 3); proboscis short (i.e. no longer than palps) with large fleshy labellae and female with well developed mandibles; wings with cell $r_{5}$ open, vein $r_{4}$ with appendix. Genitalia: male with bifid gonostyli (Fig. 6), confirming placement within the Pangoniini; tergite 9 sclerotised along basal margin (Fig. 7); female with tergite 9 undivided but tergite 10 with median membraneous fold (Fig. 9); sternite 8 (Fig. 10) subquadrate; genital fork without combs and spermathecal ducts not sclerotised or expanded at base (Fig. 8).

\section{Boliviamyia fairchildi sp.nov.}

Description of female (Fig. 11). Head - Eyes bare and without pattern in life. Frons (Fig. 1) index 1.7, diverging towards antennae, yellowish-grey pollinose becoming browner towards vertex; callus dark brown, roughly oval in shape, well separated from eye margins. Subcallus concolorous with frons, but with orange ground colour showing through the yellowish-grey tomentum. Clypeus and parafacials similar to subcallus but with coarse, mostly black hairs. Antennae (Fig. 2) orange brown, flagellum becoming darker apically; scape and pedicel with thin greyish tomentum and short black hairs. Palps (Fig. 3) concolorous with clypeus, short and swollen at base, with a narrow dorsal groove. Proboscis short, not longer than palps, the labellae large and fleshy and mandibles well developed. 


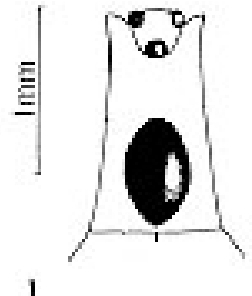

1
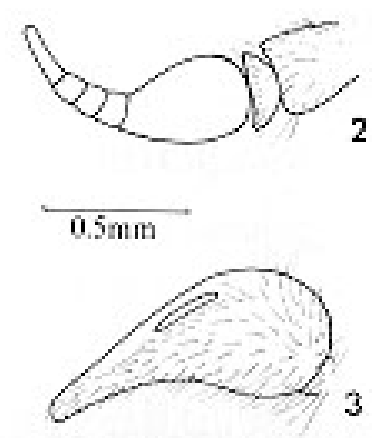

Boliviamyia fairchildi sp. n. Fig. 1: female frons. Fig. 2: female antenna. Fig. 3: female palp.

Thorax - Scutum dark brown with narrow lighter grey median stripe on anterior two-thirds (which sometimes appears brown when viewed from behind), a pair of narrow grey sublateral stripes that expand inwardly beyond the transverse suture (leaving a narrower brown median line) and are linked along suture to grey lateral margins (which are orange-brown in ground colour); mostly short black haired but some pale hairs at least anteriorly. Pleura with background colour orangebrown on katatergite, upper two-thirds of anepimeron and anepisternum and upper third of katepisternum, otherwise black; entirely grey pollinose with black hairs. Scutellum dull orangebrown through grey tomentum, the hairs pale (sometimes mostly black on disk). Legs: coxae as pleura; femora blackish with thin grey tomentum;

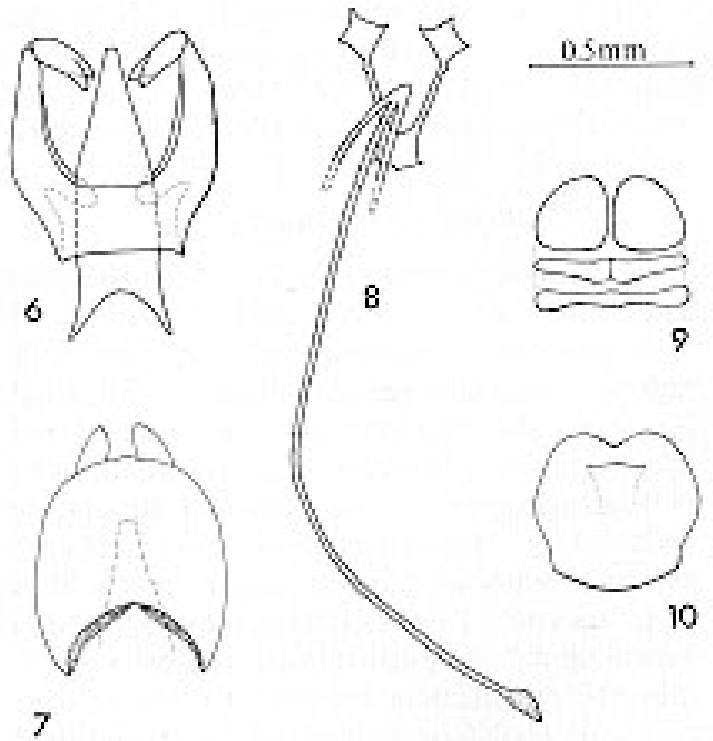

Boliviamyia fairchildi sp. n. genitalia - Fig. 6: male, simplified ventral aspect. Fig. 7: male tergite 9. Fig. 8: female, genital fork and spermathecal ducts. Fig. 9: female, simplified dorsal aspect. Fig. 10: female, sternite 8 .

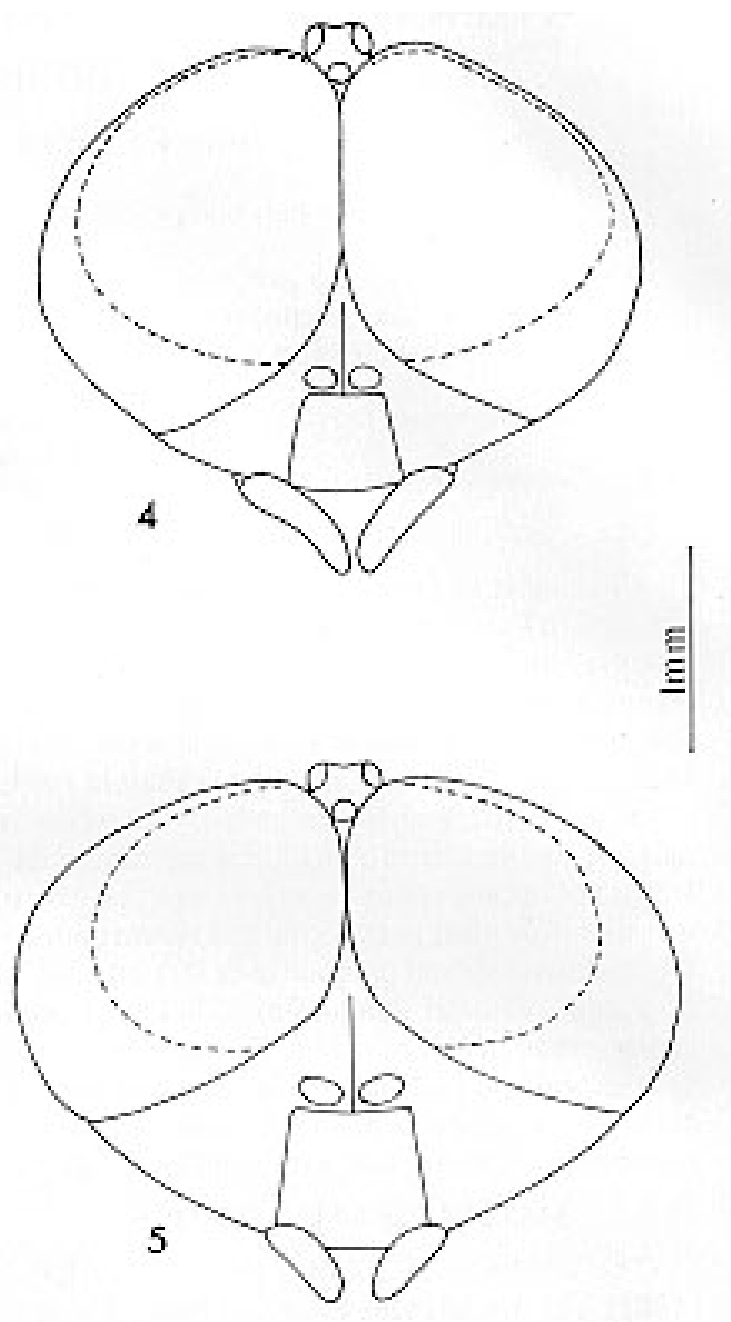

Male head viewed from front; the dashed line indicates extent of enlarged upper median facets - Fig. 4: Boliviamyia fairchildi sp. n. Fig. 5: Fairchildimyia penai Coscaron \& Philip.

tibiae and tarsi dark brown with black tips; hairs black. Wings lightly smoky but with extreme base (i.e. as far as vein h) contrasting pale yellow; costal cell brown; stigma light brown. Cell $\mathrm{r}_{5}$ open and vein $r_{4}$ with appendix. Halteres with brown stem and yellowish knob. Squamae concolorous with base of wing.

Abdomen - Dorsally dark brown with greyish hind-margins that expand laterally and (except on tergite 1) into large median triangles. Hairs mostly concolorous with background. Venter dark brown with grey hind-margins and hairs concolorous with background.

Lengths - Body 7 - $9.5 \mathrm{~mm}$; wing 7 - $9 \mathrm{~mm}$.

Description of male - Similar to female except for sexual differences. Upper median eye facets large, clearly differentiated from lower facets and 


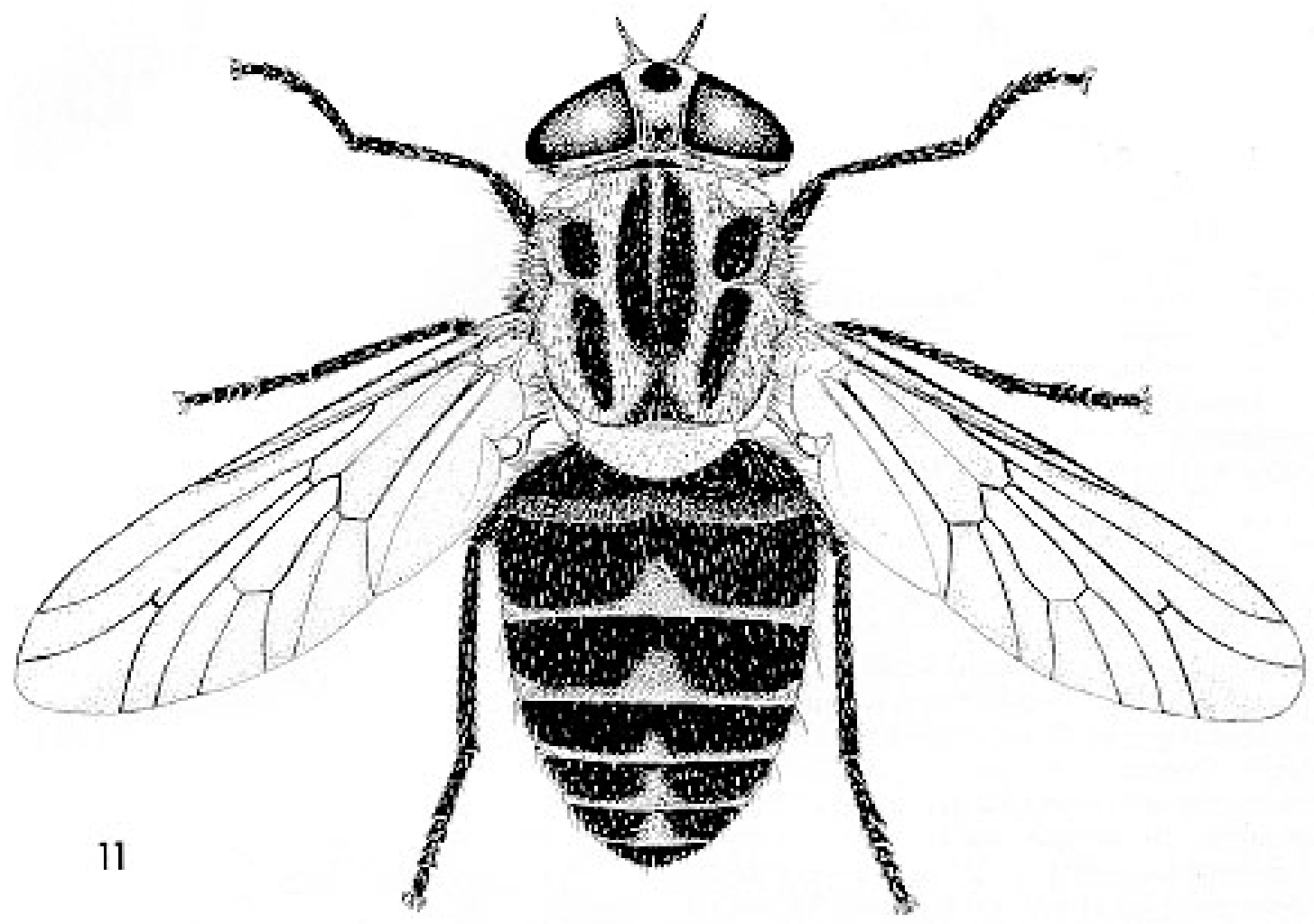

Fig. 11: dorsal view of female Boliviamyia fairchildi $\mathrm{sp} . \mathrm{n}$.

occupying approximately $70 \%$ of eye area (Fig. 4). Palps more slender, without groove. Abdomen with grey pattern slightly reduced. Femora black, contrasting with dark yellow-brown tibiae.

Material examined - BOLIVIA: Dept. Santa Cruz: Holotype (F), Prov. Andrés Ibañez, Potrerillo del Guenda, 17 42.3'S, 63 27.0'W, 510m, 6.x.1993 JLA,PB,MJRH, NHM; Paratypes: 1(M), 252(F), same as holotype but dates from 6.-10.x.1993 FSCA, MNKM, NHM; 1(F), Prov. Ichilo, Parque Amboro, Rio Saguayo, 16.ix.1990 PB, MNKM; 1(F), Prov. Santiesteban, Saavedra, ix. 1990 JLA, MNKM.

Collecting details - During early October 1993, two cloth canopy traps, adapted from Catts (1970) and Hribar et al. (1991), were deployed $100 \mathrm{~m}$ apart in a forest clearing at Potrerillo del Guenda. One was pthalogen-blue, the other was black and both were baited with 1-octen-3-ol (released at approximately $12 \mathrm{mg} /$ day), an effective bait for tabanids (French \& Kline 1989). Over a three day period the blue and black traps caught, respectively, 31 and 203 B. fairchildi, the highest daily total being 127 in the black trap. During a concurrent 12 month operation of a single black canopy trap at Potrerillo, 14 August 1993 to 26 August 1994, B. fairchildi was captured only during the period 28 August to 8 October 1993 , with $86.8 \%$ of captures $(66 / 76)$ being made in a single week, 18-23 September. Clearly this species has only a very limited, seasonal period of flight activity. The single trap was positioned in an open site, cleared for pasture, which may be the reason for the lower catch there compared to the forest sites. During October 1993, specimens of $B$. fairchild $i$ were also collected from a horse at Potrerillo, demonstrating that this species has the potential to be a biting pest, but the extent of this role is presently unknown.

\section{REMARKS}

Boliviamyia is similar to Fairchildimyia Philip \& Coscarón, 1971 in general appearance and will key to Fairchildimyia in Chainey et al. (1994), but in Fairchildimyia the eyes are densely hairy in both sexes and in the female an eyeband is present (this is exceptional in Pangoniinae) and mandibles are absent. The eyes of male Boliviamyia occupy a greater proportion of the head than in male Fairchildimyia (Figs 4, 5). The wings of Fairchildimyia are milky in appearance with the veins edged brown, whereas in Boliviamyia they are evenly lightly tinted with no concentration of colour around the veins and not appearing milky. In Coscarón (1976) Boliviamyia keys to Protosilvius Enderlein, 1922 of southeastern Brazil (reviewed by Fairchild 1962). However, 
Protosilvius females differ by having a narrow parallel sided frons without callus, slender palps without dorsal groove and mandibles apparently absent, and both sexes have the antennal flagellum with very short and/or irregularly formed basal plate and the apical flagellomeres very long and slender. In Fairchild (1969) Boliviamyia keys to the geographically separated Apatolestes Williston, 1885 (found in western Canada and U.S.A. and northwestern Mexico), but Apatolestes has the antennal flagellum annulate, lacking a basal plate.

Etymology - This new species is dedicated to the memory of GB Fairchild who died while this paper was in preparation.

\section{Esenbeckia (Esenbeckia) gracilipalpis sp. nov.} (Figs 12-14, 19)

Description of female - Head. Frons (index 5, Fig. 12) greyish yellow-brown pollinose, with ill defined narrow dark brown callus. Subcallus concolorous with frons; clypeus and parafacials somewhat greyer. Beard whitish, aurigenal hairs black. Antennae (Fig. 13): scape and pedicel yellow-brown pollinose with black hairs; flagellum orange, becoming darker on terminal flagellomeres. Palps (Fig. 14) brown, very long and slender with dark hairs, which on outer surface are mostly confined to the rim. Proboscis (Fig. 19) slightly less than one and a half times height of head in length, with slender black labellae and pseudotracheae present.

Thorax - Scutum orange-brown with rather long yellow-brown hairs. Pleura a little greyer with mostly pale yellowish hairs, except apically on anepisternum where hairs are black. Legs black haired: fore coxae grey pollinose with mixed whitish and black hairs; fore and mid-femora brown, sometimes darker on antero-dorsal surfaces, becoming paler apically; fore and mid-tibiae yellowbrown, but not strongly contrasting with femora; hind femora black, hind tibiae dark brown. Wings light brown but more yellowish in costal and basal cells. Tegula with a few yellow hairs, otherwise black haired. Halteres yellow-brown.

Abdomen - Tergite 1 pale yellow. Tergite 2 black-brown with narrow yellow-brown hind-margin. Rest of tergites black but tergite 3 with slightly pale hind-margin. Hairs of dorsum mostly black but tergite 1 with pale yellow hairs on hind-margin and rest of tergites with small pale tufts on hind corners. Sternites similar but with white hairs on hind-margins.

Lengths - Body 15.5 - $20 \mathrm{~mm}$, wing $16-19.5 \mathrm{~mm}$.

Male unknown.

Material examined - BOLIVIA: Dept. Santa Cruz: Holotype (F), Prov. Andrés Ibañez, Potrerillo del Guenda, 17 42'20”S, 63 27'25”W, 510m, 8.xi.1992 PB, NHM; Paratypes: 3(F), same data as
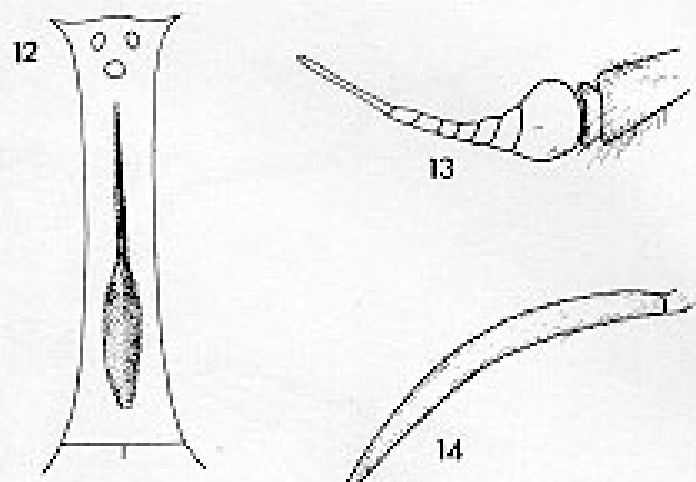

13
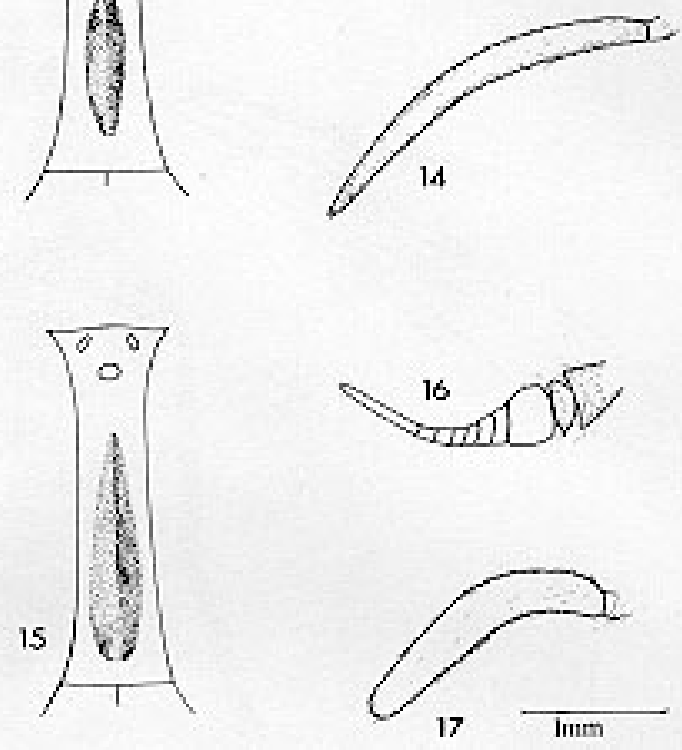

Figs 12-14 - Female Esenbeckia gracilipalpis sp. n. Fig. 12: frons. Fig. 13: antenna. Fig. 14: palp. Figs 15-17: female Esenbeckia griseipleura sp. n. Fig. 15: frons. Fig. 16: antenna. Fig. 17: palp.
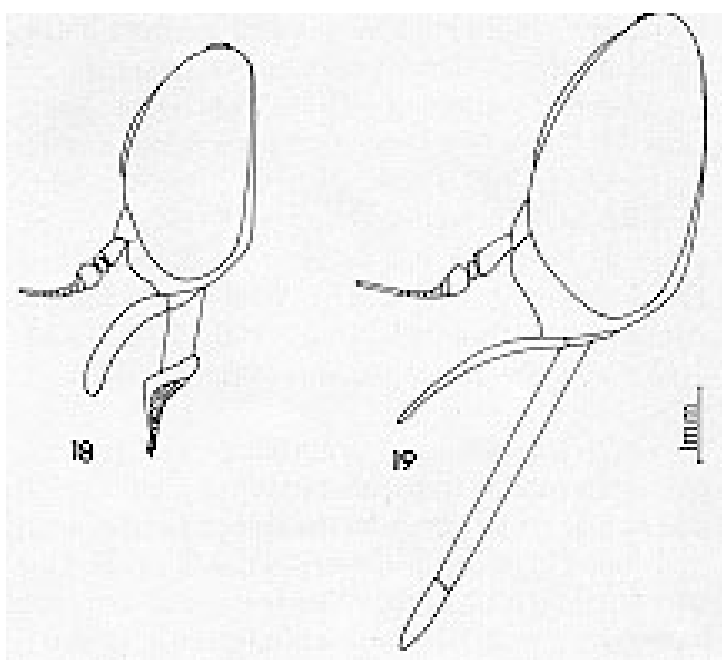

Lateral profile of female head - Fig. 18: Esenbeckia griseipleura sp. n. Fig. 19: Esenbeckia gracilipalpis sp. n.

holotype; 2(F), same data, 23.-29.x.1993; 7(F), same data, 30.x.-5.xi.1993; 8(F) same data, 6.-12.xi.1993; 30(F), same data, 13.-19.xi.1993 NHM, FSCA, MNKM, UNH (an additional six females in poor condition are excluded from the type series). 


\section{REMARKS}

Differs from other species with yellow, orange or rufous mesoscutum by having very long slender palps, long proboscis with slender labellae and by leg and abdominal pattern. It will not key out satisfactorily in Wilkerson and Fairchild's (1983) review of Esenbeckia (Esenbeckia). E. gracilipalpis is structurally closest to E. pechumani Wilkerson \& Fairchild, 1983 but that species is smaller (14 - $16 \mathrm{~mm})$ and has tergites $1-2$ and posterior third of tergite 3 translucent yellowish with a diamond shaped dark median mark on tergite 2; sternites 1 - 3 translucent pale yellowishbrown, sternites without white haired hind-margins and sternite 3 with lateral dark spots; fore legs and mid tibiae mostly golden yellow haired.

Etymology - The specific name gracilipalpis refers to the very long, slender palps.

\section{Esenbeckia (Esenbeckia) griseipleura sp. nov.} (Figs 15-18)

Description of female. Head - Frons (index 4, Fig. 15) yellowish-brown pollinose, becoming paler basally, with dark brown callus. Subcallus concolorous with base of frons. Clypeus and parafacials slightly more greyish than subcallus. Beard whitish. Antennae (Fig. 16): scape and pedicel yellow-brown pollinose with orange-brown hairs; flagellum orange, becoming darker on terminal flagellomeres. Palps (Fig. 17) orange, largely flattened at sides and blunt tipped; with orangebrown hairs, which on outer surface are mostly confined around rim. Proboscis (Fig. 18) about two-thirds height of head in length, with labellae black-brown and pseudotracheae present, labium dark brown through greyish tomentum.

Thorax - Scutum orange-brown with concolorous hairs, without pattern. Pleura contrastingly grey with whitish hairs, except apically on anepisternum and around anterior spiracle where hairs are orange-brown. Legs orangebrown, mostly with concolorous hairs, but hairs on hind tibiae mostly dark. Wings lightly brown stained from basal cells and $\mathrm{r}_{4}$ fork anteriorly (more intensely stained in costal cell), otherwise light greyish-brown. Tegula with a few black hairs, otherwise golden-yellow haired. Halteres orange.

Abdomen - Dorsum concolorous with mesoscutum. Hairs mostly black but many orangebrown hairs on tergite 1 and a few such hairs on hind corners of each tergite. Venter yellow-brown with concolorous hairs, paler than dorsum.

Lengths - Body 13 - 14 mm, wing 13.5 - 14.75 $\mathrm{mm}$.

Male unknown.

Material examined - BOLIVIA: Dept. Santa
Cruz: holotype (F), Prov. Nuflo de Chavez, c25 $\mathrm{km} \mathrm{N}$ of Concepción, Las Madres, 8.-9.ii.1993, on horse, JLA,PB,JEC,MJRH, NHM; paratypes: 1(F), same data as holotype, NHM; 1(F), Perseverencia; 14.ii.1991 PB, MNKM; 1(F), Prov. Andrés Ibañez, Cotoca, 18.i.1991 JLA, MNKM; 1(F), Prov. Velasco, San Ignacio de Velasco, La Piedra, 10.ii.1993 JLA,PB,JEC,MJRH, NHM.

\section{REMARKS}

Keys to E. vulpes (Wiedemann 1828) in Wilkerson and Fairchild's (1983) review of Esenbeckia (Esenbeckia). E. vulpes is larger (18.5 - $19 \mathrm{~mm}$ ) and has frons with a linear callus (this may not be visible in rubbed specimens), outer surface of palps fringed with black hairs, posterior tibiae with orange hairs and abdomen with mostly rufous hairs.

Etymology - The specific name griseipleura refers to the strongly contrasting grey pleura.

\section{Esenbeckia (Esenbeckia) planaltina Fairchild, 1971}

The following material from Dept. Santa Cruz, BOLIVIA is considered to belong to E. planaltina: 1(F), Prov. Santiesteban, San Pedro, xii.1990 (C Proett) MNKM; 7(F), Prov. Andrés Ibañez, Potrerillo del Guenda, 13.ix.1993 (PB) MNKM, NHM; 1(F), same locality, 9.x.1993 (JLA, PB, MJRH); 2(F), 17 40’20”'S, 63 27'25"W, 28.viii.1993 (PB) MNKM. All these specimens have the abdomen dorsally with a slightly greenish tinge and faint suggestions of a narrow brownish median stripe. This taxon was proposed as a subspecies of E. osornoi Fairchild, 1942 and was so treated by Wilkerson and Fairchild (1983). Wilkerson and Fairchild (1983 key) state that $E$. osornoi [incl. planaltina] has the abdomen "immaculate above", but some specimens determined by them as E. osornoi do show faint traces of a narrow brownish median stripe. Wilkerson and Fairchild (1983) segregated E. osornoi into four subspecies but thought that these would not be sustainable once further material became available. Since then, Fairchild and Burger (1994) have placed E. planaltina as a distinct species, occurring in southern Brazil (Goiás, Minas Gerais, São Paulo, Mato Grosso), and geographically separate from E. osornoi which occurs from Costa Rica to Brazil (Bahia). They synonymized the other subspecies [E. osornoi guianense Fairchild, 1942 and E. osornoi meridionale Fairchild, 1942] under E. osornoi. Kröber's (1934) record of E. ferruginea (Macquart, 1838) [= E. planaltina Fairchild] from Bolivia was considered doubtful by Chainey et al (1994) [as E. osornoi Fairchild], but is now presumed to refer to E. planaltina Fairchild, 1971. 


\section{ACKNOWLEDGEMENTS}

To Mr Graham du Heaume, International Institute of Entomology, NHM for preparing Fig. 11, to Dr John F Burger, UNH for his helpful comments, to Dr Richard Roberts, FSCA for the loan of Fairchildimyia material, to José Luis Aramayo and Paolo Bettella, MNKM and to Dr James J McGrane (LIDIVET, Santa Cruz), for their support in fieldwork in Bolivia.

\section{REFERENCES}

Catts EP 1970. A canopy trap for collecting Tabanidae. Mosq News 30: 472-474.

Chainey JE, Hall MJR, Aramayo JL, Bettella P 1994. A preliminary checklist and key to the genera and subgenera of Tabanidae (Diptera) of Bolivia with particular reference to Santa Cruz Department. Mem Inst Oswaldo Cruz 89: 321-345.

Coscarón S 1976. Contribucion al conocimiento de los Tabanidae neotropicales II. Los Pangoniini del sur de Sudamerica y datos sobre la tribu Scepsidini. Rev Mus La Plata, NS, 12: 75-116.

Enderlein G 1922. Ein neues Tabanidensystem. Mitt Zool Mus Berl, 10: 333-351.

Fairchild GB 1942. Notes on Tabanidae from Panama. VIII. The genera Pityocera, Scione and Esenbeckia. Ann Entomol Soc Am 35: 183-199.

Fairchild GB 1962. Notes on Neotropical Tabanidae III. The genus Protosilvius Enderlein. Ann Entomol Soc Am 55: 342-350.

Fairchild GB 1969. Notes on Neotropical Tabanidae XII. Classification and distribution, with keys to genera and subgenera. Arq Zool (São Paulo) 17: 199-255.

Fairchild GB 1971. A catalogue of the Diptera of the Americas south of the United States. Fasc. 28, family
Tabanidae. Mus. Zool. São Paulo, Brazil, 163 pp.

Fairchild GB, Burger JF 1994. A catalog of the Tabanidae (Diptera) of the Americas South of the United States. Mem Am Entomol Inst 55: 1-249.

French FE, Kline DL 1989. 1-octen-3-ol, an effective attractant for Tabanidae. J Med Entomol 26: 459461.

Hribar LJ, Leprince DJ, Foil LD 1991. Design for a canopy trap for collecting horse flies (Diptera: Tabanidae). J Am Mosq Control Assoc 7: 657-659.

Kröber O 1934. Catalogo dos Tabanidae da America do Sul e Central, incluindo o Mexico e as Antilhas. Rev Entomol (Rio J) 4: 222-276.

Macquart J 1838. Diptères exotiques nouveaux ou peu connus. [1 (1)]. Mém Soc R Sci Agric Arts Lille 1838: 9-225. [Reprinted separately with the pagination 5221.]

McAlpine JF 1981. Morphology and terminology adults, p. 9-63. In JF McAlpine, BV Peterson, GE Shewell, HJ Teskey, JR Vockeroth, DM Wood (eds) Manual of Nearctic Diptera 1. Research Branch, Agriculture Canada (Monograph No.28).

Philip CB, Coscarón S 1971. New Neotropical Tabanidae. II. Three primitive undescribed Pangoniine-like flies of unusual interest from Chile. Pap Avulsos Zool (São Paulo) 23: 127-136.

Wiedemann CRW 1828. Aussereuropäische zeiflügelike Insekten [part]. 1, Hamm, xxxii + 608 pp.

Wilkerson RC, Fairchild GB 1983. A review of the South American species of Esenbeckia subgenus Esenbeckia (Diptera: Tabanidae). J Nat Hist 17: 519567.

Williston SW 1885. On the classification of North American Diptera. Entomol Am 1: 10-13. 